DOI: $10.24014 /$ jdr.v31i1.10280

\title{
PENGUATAN NILAI-NILAI KEAGAMAAN MELALUI LABORATORIUM SOSIAL DI TANAH DATAR
}

\author{
Irwandi $^{1^{*}}$, Zulamri $^{2}$ \\ ${ }^{1}$ Institut Agama Islam Negeri Batusangkar \\ ${ }^{2}$ Universitas Islam Negeri Sultan Syarif Kasim Riau \\ *Email: irwandi@iainbatusangkar.ac.id
}

\begin{tabular}{|c|c|}
\hline Kata kunci & Abstrak \\
\hline $\begin{array}{l}\text { Pengembangan } \\
\text { masyarakat, } \\
\text { Islam, nilai } \\
\text { agama, } \\
\text { laboratorium } \\
\text { sosial }\end{array}$ & $\begin{array}{l}\text { Laboratorium sosial berfungsi untuk perluasan dan penguatan keilmuan } \\
\text { rumpun ilmu sosial di perguruan tinggi. Penelitian ini bertujuan untuk } \\
\text { mengetahui peran dan fungsi laboratorium sosial dalam penguatan nilai- } \\
\text { nilai keagamaan di Kabupaten Tanah Datar. Penelitian ini menggunakan } \\
\text { metode kualitatif dengan pendekatan deskriptif. Penelitian ini } \\
\text { menemukan, kegiatan laboratorium sosial dimulai dari persiapan, } \\
\text { perencanaan program, pelaksanaan, dan evaluasi. Kegiatan laboratorium } \\
\text { meliputi literasi sosial keagamaan, aktivitas sosial keagamaan, dan } \\
\text { dokumentasi sosial keagamaan. Implikasi kegiatan dapat dilihat dari } \\
\text { peran laboratorium sosial dalam membantu masyarakat } \\
\text { menumbuhkembangkan kegiatan-kegiatan keagamaan. Laboratorium } \\
\text { sosial menjadi salah satu wadah untuk mengaplikasikan keilmuan } \\
\text { terutama bidang pemberdayaan masyarakat. Kehadiran laboratorium } \\
\text { sosial merupakan kontribusi perguruan tinggi dalam bidang } \\
\text { pengembangan kegiatan keagamaan. }\end{array}$ \\
\hline Keywords & Abstract \\
\hline $\begin{array}{l}\text { Community } \\
\text { development, } \\
\text { Islam, religious } \\
\text { values, social } \\
\text { laboratories }\end{array}$ & $\begin{array}{l}\text { The social laboratory functions for the expansion and strengthening of } \\
\text { social science knowledge in universities. This study aims to determine the } \\
\text { role and function of social laboratories in strengthening religious values } \\
\text { in Tanah Datar District. This research uses a qualitative method with a } \\
\text { descriptive approach. This research found that social laboratory activities } \\
\text { started in preparation, programming, implementation, and evaluation. } \\
\text { Laboratory activities include religious social literacy, religious social } \\
\text { activities, and religious social documentation. The implication of the } \\
\text { activity can be seen from the role of the social laboratory in helping the } \\
\text { community to develop religious activities. A social laboratory is a place } \\
\text { for applying science, especially in the field of community empowerment. } \\
\text { The presence of social laboratories is the contribution of universities in } \\
\text { the field of developing religious activities. }\end{array}$ \\
\hline
\end{tabular}

\section{Pendahuluan}

Tuntutan mengembangkan jurusan Pengembangan Masyarakat Islam (PMI) sesuai Kerangka Kualifikasi Nasional Indonesia (KKNI) berbasis akreditasi perlu dilakukan lebih komprehensif dengan melibatkan stakeholders. Ini akan memberikan kontribusi 
besar terhadap mahasiswa dan kelanjutan jurusan PMI ke depan. Salah satu bentuk pengembangaan tersebut adalah dengan menjalin kerja dengan pemerintah dan masyarakat. Hal ini dilakukan Institut Agama Islam Negeri (IAIN) Batusangkar yang diwakili Fakultas Ushuluddin, Adab dan Dakwah (FUAD) dengan berbagai nagari di Kabupaten Tanah Datar dan kabupaten lainnya. Salah satu nagari yang bekerja sama adalah Nagari Parambahan, Kecamatan Lima Kaum, Kabupaten Tanah Datar, Provinsi Sumatra Barat.

Kerja sama antara Jurusan PMI FUAD IAIN Batusangkar dengan Wali Nagari Parambahan dalam bentuk pendirian laboratorium sosial, yang dikhususkan pada bidang pendampingan kegiatan keagamaan dan memfasilitasi kebutuhan-kebutuhan lain. Kegiatan tersebut melibatkan tim mahasiswa Jurusan PMI dibantu mahasiswa jurusan lain di lingkungan FUAD. Kerja sama tim merupakan sekelompok orang-orang yang bekerja bersama untuk mencapai tujuan yang sama, dan tujuan tersebut akan lebih mudah diperoleh dengan melakukan kerja sama tim daripada dilakukan sendiri (Lawasi \& Triatmanto, 2017).

Laboratorium sosial didirikan pada 2018 di Nagari Parambahan dengan tujuan: (a) Sebagai wadah bagi mahasiswa PMI untuk mempraktikkan ilmu pengetahuan secara langsung di tengah-tengah masyarakat; (b) Membantu nagari mengembangkan kegiatan keagamaan bidang akidah, ibadah, syariah, serta sosial keagamaan; dan (c) Sebagai bentuk kepedulian pihak perguruan tinggi dalam mengembangkan tri dharma perguruan tinggi, khususnya bidang pengabadian kepada masyarakat.

Penelitian tentang penguatan fungsi laboratorium sosial banyak dilakukan peneliti sebelumnya, seperti Utari (2017) yang meneliti penguatan dan perluasan fungsi laboratorium pada rumpun ilmu sosial di perguruan tinggi. Penelitian tersebut menekankan perlunya perguruan tinggi mengubah paradigma tradisional terhadap laboratorium ilmu sosial. Selain penguatan fungsi laboratorium, perluasan juga dapat dilakukan sehingga laboratorium tidak sekadar menjadi teaching/learning lab, namun juga ranah penelitian dan pengabdian kepada masyarakat.

Penelitian tentang laboratorium sosial dalam penguatan nilai-nilai keagamaan dipertegas pada perguruan tinggi keagamaan Islam. Riyadi (2019) mengemukakan bahwa fase pengembangan laboratorium dakwah pada Fakultas Dakwah dan Komunikasi UIN Walisongo Semarang dilakukan melalui empat tahap, yakni fase inisiasi dan pembangunan sistem penjaminan mutu, fase optimalisasi kemampuan penunjang akademik, fase intensifikasi dan ekstensifikasi pelayanan penelitian, serta fase peningkatan kapasitas eksternal.

Terkait manfaat laboratorium Sofah \& Sucipto (2017) menjelaskan optimalisasi pemanfaatan laboratorium sebagai tempat untuk meningkatkan kompetensi mahasiswa, seperti melaksanakan praktik konseling individu, praktik konseling kelompok, praktik bimbingan kelompok, dan mengujicobakan media bimbingan dan konseling. Dosen dapat mengoptimalkan pemanfaatkan laboratorium sebagai tempat untuk pengembangan pembelajaran, penelitian serta mengoptimalkan fungsi laboratorium 
untuk mengajak mahasiswa melakukan praktik-praktik bimbingan konseling guna menunjang tercapainya kurikulum berbasis KKNI.

Kegunaan laboraturium sosial yang diarahkan pada pengkajian agama dikemukan oleh AS et al. (2019), bahwa pembelajaran pendidikan agama Islam yang dilakukan di luar jam pelajaran merupakan kegiatan keagamaan dalam rangka mengaktualisasikan pendidikan agama yang dilakukan di dalam jam pelajaran. Pembelajaran pendidikan agama Islam yang dilakukan di luar jam pelajaran seperti salat zuhur berjamaah, salat jumat, pelatihan membaca Al-Qur'an bagi siswa yang mengalami kesulitan atau tidak dapat membaca Al-Qur'an dengan lancar, kantin kejujuran, kurban, dan Peringatan Hari Besar Islam (PHBI) sangat mendukung program pembelajaran keagamaan yang dilakukan secara formal. Sehingga siswa mampu mengaplikasikan pendidikan agama Islam dengan baik dan benar.

Peran dan fungsi laboraturium sosial bagi dosen dan mahasiswa menjadi fokus penelitian Mustofa (2019) yang menjelaskan temuan, pengabdian masyarakat digunakan untuk praktik pembelajaran layanan dalam kursus manajemen madrasah dengan pendekatan Pengembangan Masyarakat Berbasis Aset atau Asset Based Community Development (ABCD). Sekolah Diniyah di lokasi layanan dipilih untuk menjadi laboratorium pengembangan kapasitas bagi para dosen, sehingga mereka dapat memberdayakan potensinya untuk menanggapi perubahan peraturan dan tantangan global. Serangkaian kegiatan dilakukan untuk memberdayakan guru dan siswa. Hasil dari kegiatan menunjukkan peran para pemangku kepentingan dari Lembaga Pendidikan Al-Qur'an dalam memobilisasi potensi dan asetnya, untuk meningkatkan kapasitasnya dengan mempraktikkan layanan pembelajaran manajemen madrasah.

Berbeda dengan penelitian-penelitian sebelumnya, penelitian ini fokus mengulas kontribusi mahasiswa Jurusan PMI yang didampingi para tenaga pendidik, dalam menumbuhkembangkan kegiatan laboratorium sosial di Kabupaten Tanah Datar. Penelitian ini bertujuan untuk mengetahui penguatan nilai-nilai keagamaan melalui laboratorium sosial di Nagari Parambahan, Kecamatan Lima Kaum, Kabupaten Tanah Datar.

\section{Metode}

Penelitian ini menggunakan metode kualitatif dengan pendekatan deskriptif. Proses penelitian kualitatif lebih dimaksudkan untuk memahami masalah-masalah manusia dalam konteks sosial dengan menciptakan gambaran menyeluruh dan kompleks yang disajikan, melaporkan pandangan terperinci dari sumber informasi, serta dilakukan dalam setting yang alamiah tanpa adanya intervensi apapun dari peneliti (Hendriansyah, 2012). Informan penelitian ini terdiri atas dosen, mahasiswa, wali nagari, unsur lembaga nagari, dan masyarakat. Pengumpulan data dilakukan melalui wawancara, obsevasi dan dokumentasi. Data yang terkumpul kemudian dianalisis menggunakan teknik analisis model interaktif dengan langkah-langkah sebagai berikut: mereduksi data, menampilkan data, dan menarik kesimpulan. 


\section{Hasil dan Pembahasan}

Nagari Parambahan terletak di kaki Gunung Marapi, merupakan bagian dari lima nagari yang ada di Kecamatan Lima Kaum, Kabupaten Tanah Datar. Penduduk Nagari Parambahan berjumlah 2.561 orang dengan mata pencarian utama bertani dan berkebun. Penduduk Nagari Parambahan $100 \%$ penganut agama Islam yang ditandai dengan berbagai sarana prasarana ibadah untuk menunjang kegiatan agama dan sosial keagamaan. Di lokasi tersebut terdapat dua masjid dan enam surau. Untuk kegiatan keagamaan, didukung keberadaan Taman Pendidikan Al-Qur'an/ Seni Al-Qur'an (TPA/TPSA), Taman Pendidikan Tahfizul Qur'an, dan beberapa kelompok pengajian.

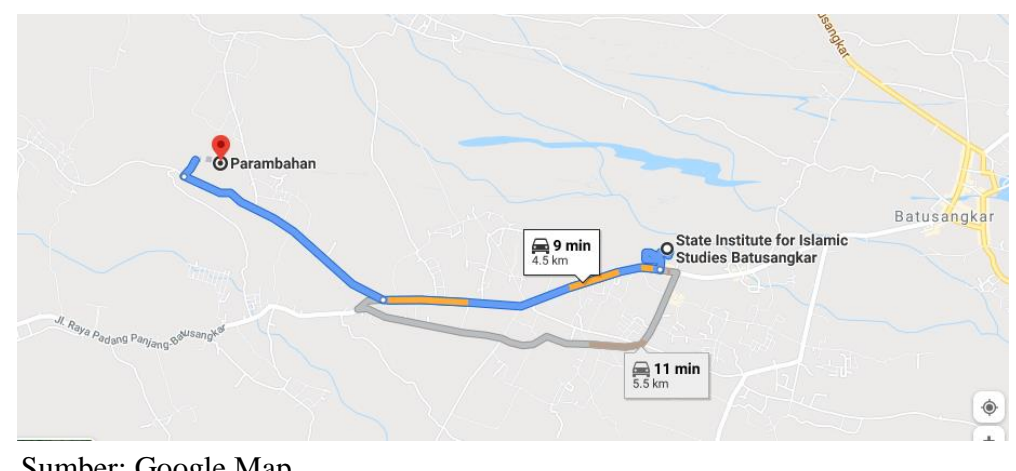

Sumber: Google Map

Gambar 1. Lokasi laboratorium sosial Nagari Parambahan, Tanah Datar.

Sarana dan prasarana yang tersedia di Nagari Parambahan belum sepenuhnya dimanfaatkan oleh masyarakat untuk kegiatan rutin keagamaan seperti salat lima waktu secara berjamaah dan wirid pengajian secara periodik. Pendidikan TPA/TPSA dikelola sesuai petunjuk Pemerintah Daerah Kabupaten Tanah Datar dan Kementerian Agama Kabupaten Tanah Datar. Pemanfaatan sarana prasarana yang belum optimal dibenarkan oleh Wali Nagari Parambahan, sehingga hal itu menjadi salah salah prioritas Pemerintah Nagari dalam pembangunan yang dituangkan dalam Rencana Pembangunan Jangka Menengah (RPJM) Nagari, khususnya bidang keagamaan didukung oleh Dana Desa (DD) dari pemerintah pusat dan Anggaran Dana Desa (ADD) dari kabupaten.

\section{Laboratorium Sosial di Nagari Parambahan}

Laboratorium adalah suatu tempat di mana dilakukan kegiatan kerja untuk melakukan sesuatu. Tempat ini dapat berupa suatu ruangan tertutup, kamar, atau ruangan terbuka (Emda, 2017). Keberadaan laboratorium sosial di Nagari Parambahan merupakan rancangan bersama antara pihak nagari dan pihak FUAD IAIN Batusangkar. Pelaksanaannya diwakili rumah kreatifitas mahasiswa Jurusan PMI dalam wadah Islamic Community Development (ICD). Pelaksanaan kegiatan dimulai dengan perencanaan pembentukan laboratorium, pemenuhan sarana prasarana laboratorium, penggunaan sarana prasarana laboratorium, dan pemeliharaan. Untuk menjamin keberlangsungan laboratorium sosial keagamaan, disusunlah konsep laboratorium sosial keagamaan dengan langkah-langkah sebagai berikut: 


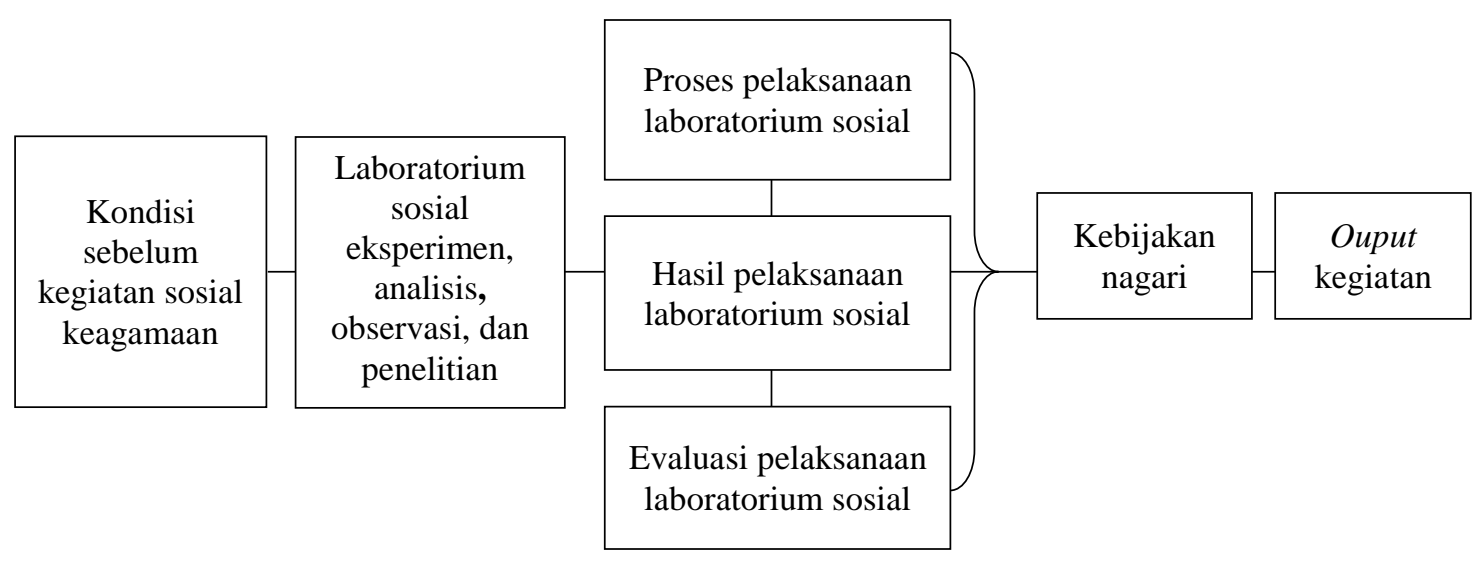

Gambar 2. Program kegiatan laboratorium sosial

Konsep program kegiatan laboratorium sosial ini berdasarkan tahapan manajemen pengembangan masyarakat Islam. Proses community development terdiri tahapan engagement, assessment, perencanaan program, pemformulasian rencana aksi, implementasi, evaluasi dan hasil perubahan, dan tahapan terminasi (Rinaldy et al., 2017). Penyusunan program laboratorium sosial berorientasi pada kemandirian mahasiswa dalam pengelolaan kegiatan, karena dibantu oleh lembaga-lembaga di nagari seperti kerapatan adat nagari, alim ulama, cerdik pandai, pemuda, dan bundo kanduang. Perpaduan seluruh unsur ini diharapkan mampu membangkitkan marwah bidang keagamaan dan sosial. Hal ini berkaitan dengan manajemen pengembangan masyarakat Islam. Peningkatan kapasitas pemberdayaan masyarakat juga didudukung oleh manajemen pemberdayaan masyarakat.

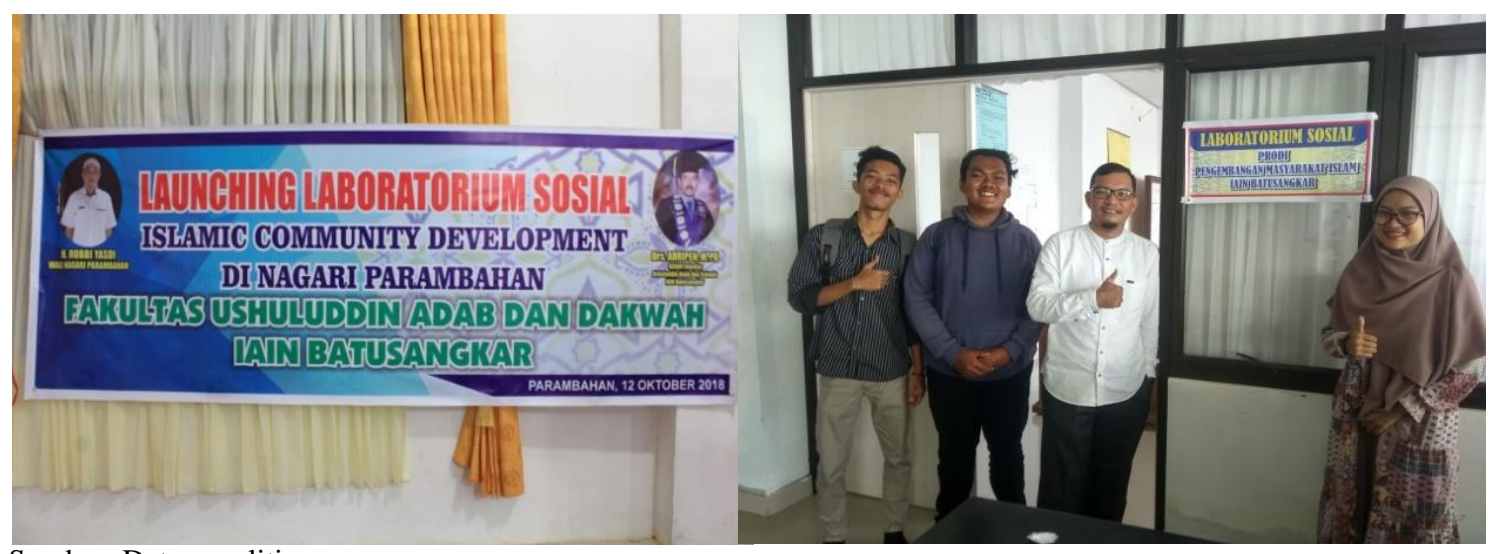

Sumber: Data penelitian

Gambar 3. Peresmian laboratorium sosial

Kepedulian wali nagari dalam pembentukan laboratorium sosial berdampak pada penyediaan sarana dan prasarana kegiatan, seperti ruangan kegiatan dan fasilitas penunjang lainnya. Penyediaan fasilitas ini memudahkan koordinasi dan konsolidasi antara pihak kampus yang diwakili oleh dosen pembimbing dan mahasiswa dengan pihak nagari. Malone \& Crowstone dalam Juliawati (2012) mengartikan aktivitas 
koordinasi sebagai pengelolaan ketergantungan antar kegiatan (managing dependencies between activities). Secara administrasi seluruh penyediaan sarana dan prasarana juga memperlihatkan keseriusan pihak nagari dalam menfasilitasi seluruh kegiatan laboratorium sosial.

\section{Kontribusi Laboratorium Sosial}

Kontribusi dalam pengertian pengembangan masyarakat Islam adalah suatu sistem tindakan nyata alternatif model pemecahan masalah umat dalam bidang sosial, ekonomi, dan lingkungan dalam perspektif Islam. Tujuannya menstransformasikan dan melembagakan semua segi ajaran Islam dalam kehidupan keluarga (usrah) kelompok sosial (jamaah), dan masyarakat (ummah). Model empirisnya, pengembangan perilaku individual dan kolektif dalam dimensi amal saleh (karya terbaik) dengan titik tekan pada pemecahan masalah yang dihadapi oleh masyarakat (Nasril, 2015).

Keterlibatan mahasiswa dalam mengiplementasikan keilmuan pemberdayaan berhubungan dengan kemampuan mahasiswa dalam berinterkasi secara baik dengan lingkungan, karena mahasiswa berfungsi sebagai subjek dan masyarakat merupakan objek. Interaksi sosial adalah suatu hubungan antara induvidu atau lebih, di mana kelakuan individu yang satu mempengaruhi, mengubah, atau memperbaiki kelakuan individu yang lain, atau sebaliknya. Dari interaksi sosial itu maka pola penerapan keilmuan yang harus dikembangkan oleh mahasiswa adalah pola pengembangan dakwah yang berorientasi perubahan secara menyeluruh.

Dakwah dipahami sebagai suatu aktivitas yang melibatkan proses transformasi membutuhkan kesadaran masyarakat (Muhyiddin, 2019). Begitu juga dengan aktivitas pengembangan masyarakat dalam laboratorium sosial, merupakan aktivitas perubahan dan transformasi keilmuan agama untuk kemaslahatan sosial umat secara menyeluruh. Transformasi keilmuan menekankan perubahan di tengah-tengah masyarakat dan ini berkaitan dengan pola komunikasi yang dilakukan di tengah-tengah masyarakat. Penulis menemukan keterlibatan mahasiswa PMI dalam laboratorium sosial di Nagari Parambahan sebagai berikut:

\section{Persiapan}

Teknik yang dipakai dalam persiapan laboratorium sosial mengacu pada teknik partisipasi dalam metode Participatory Rural Appraisal (PRA)/ Rapid Rurral Aprraisal (RRA). Chambers (1994) yang mengembangkan metode ini mengartikan sebagai: sekumpulan pendekatan dan metode yang mendorong masyarakat pedesaan dan atau pesisir untuk turut serta meningkatkan dan mengkaji pengetahuan mereka mengenai hidup dan keadaan mereka sendiri, agar mereka dapat menyusun rencana pelaksanaannya.

Metode ini bukan sekadar pengkajian, melainkan melibatkan masyarakat dalam keseluruhan proses kegiatan sejak mulai mengenal kebutuhan, perencanaan, pelaksanaan, pemantauan, sampai mengevaluasi kegiatan. Metode ini bukan hanya untuk masyarakat pedesaan tetapi juga perkotaan, termasuk juga masyarakat pantai atau 
masyarakat pesisir. Metode ini bukan hanya masyarakat yang ikut-serta terhadap kegiatan "orang luar" melainkan sebaliknya (DKP, 2006). Dalam kegiatan yang melibatkan masyarakat, terutama masyarakat pedesaan, konsep RRA dan PRA sering digunakan oleh para peneliti maupun lembaga swadaya masyarakat (LSM) untuk mendapatkan hasil yang bermanfaat bagi masyarakat pedesaan (Zakaria, 2018).

Penyelenggaraan kegiatan laboratorium sosial dimulai dengan kegiatan sosialiasi kepada masyarakat. Sosialisasi merupakan proses belajar yang dialami seseorang untuk memperoleh pengetahuan, keterampilan, nilai-nilai dan norma-norma agar ia dapat berpartisipasi sebagai anggota dalam kelompok masyarakatnya (Abdullah \& Nasionalita, 2018). Sosialisasi dilaksanaksanan dalam rangka menyatukan visi dan misi pendirian laboratoium sosial keagamaan. Sosialisasi ini melibatkan seluruh unsur, baik dosen pembimbing dan mahasiswa, maupun unsur-unsur nagari (wali nagari, kerapatan adat nagari, kaum cerdik pandai, alim ulama, pemuda dan bundo kanduang). Pelaksanaan kegiatan sosialisasi berlangung selama dua hari. Hasil sosialisasi ini ditandai dengan penandatanganan nota kesepahaman tentang berdirinya laboratorium sosial di Nagari Parambahan.

Selanjutnya tim pengelola laboratorium melakukan penyiapan kelompok kerja. Pembentukan tim ini merupakan salah satu intervensi proses manusia yang dapat mendukung lancarnya strategi perusahaan (Bachroni, 2015). Tim mengelola laboratorium sosial terdiri atas dosen pembimbing, mahasiswa PMI, dan unsur-unsur yang mewakili masyarakat nagari. Pembentukan tim ini disahkan dalam bentuk Surat Keputusan (SK) yang dikeluarkan oleh Wali Nagari Parambahan. Tugas dan fungsi masing-masing tim disusun oleh rumah kreatifitas mahasiswa Islamic Community Development (ICD).

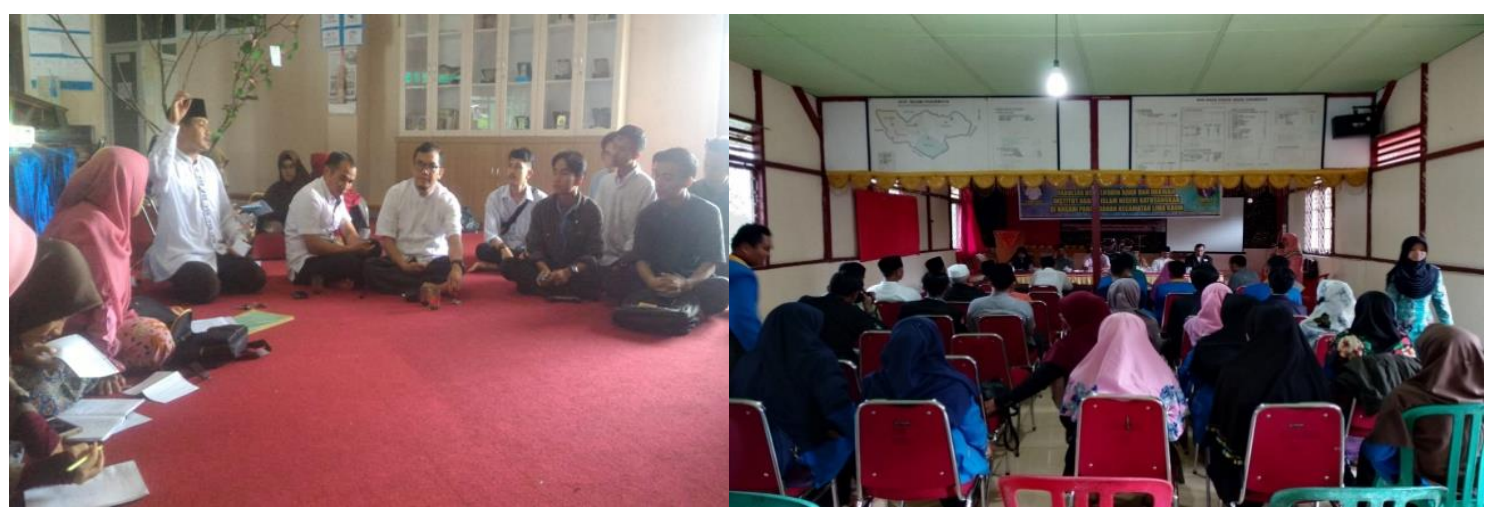

Sumber: Data penelitian

Gambar 4. Kegiatan sosialisasi laboratorium sosial.

Tim pengelola laboratorium sosial kemudian menyiapkan istrumen pengumpulan data untuk mengumpulkan dan menginventarisir permasalahan dan kebutuhan masyarakat berkaitan dengan kegiatan sosial keagamaan. Pengumpulan data dilakukan melalui wawancara, pengamatan, dan pemngumpulan dokumentasi dari masyarakat nagari. Data yang dikumpulkan kemudian dianalisis oleh pengelola laboratorium untuk 
menemukan prioritas utama yang dilaksanakan oleh tim dalam mengelola laboratorium sosial. Hasil analisis ini digunakan untuk merumuskan peta sosial keagamaan di Nagari Parambahan.

\section{Penyusunan program}

Program kegiatan laboratorium sosial disusun berdasarkan hasil analisis yang telah dilaksanakan sebelumnya. Program disusun berorientasi pada pembangunan berbasis kepercayaan (trust). Pembangunan berdasarkan kepercayaan adalah pembangunan berpola pemberdayaan seluruh rakyat, khususnya rakyat kecil, miskin dan tertinggal (Soleh, 2014). Program laboratorium sosial keagamaan dilaksanakan berdasarkan nilai-nilai kepercayaan sebagai berikut:

Tabel 1. Program laboratorium sosial di Kabupaten Tanah Datar

\begin{tabular}{|c|c|c|c|}
\hline No & Program & Bentuk Kegiatan & Keterangan \\
\hline 1 & $\begin{array}{l}\text { Literasi sosial } \\
\text { keagamaan }\end{array}$ & $\begin{array}{l}\text { 1. Perpustakaan Nagari } \\
\text { 2. Penyusunan buku panduan } \\
\text { kajian keagamaan }\end{array}$ & $\begin{array}{l}\text { Melibatkan mahasiswa } \\
\text { Jurusan Ilmu } \\
\text { Perpustakaan dan } \\
\text { Informasi Islam serta } \\
\text { mahasiswa Jurusan Ilmu } \\
\text { Alquran dan Tafsir }\end{array}$ \\
\hline 2 & $\begin{array}{l}\text { Aktivitas sosial } \\
\text { keagamaan }\end{array}$ & $\begin{array}{l}\text { 1. Peduli masalah-masalah sosial } \\
\text { 2. Pelatihan dan workshop bidang } \\
\text { keagamaan } \\
\text { 3. Penguatan lembaga sosial } \\
\text { keagamaan } \\
\text { 4. Pembentukan lembaga- } \\
\text { lembaga pengkajian bidang } \\
\text { keagamaan }\end{array}$ & \\
\hline 3 & $\begin{array}{l}\text { Dokumentasi bidang } \\
\text { sosial keagamaan }\end{array}$ & $\begin{array}{l}\text { Pembuatan video profil kegiatan } \\
\text { sosial keagamaan }\end{array}$ & $\begin{array}{l}\text { Melibatlan mahasiswa } \\
\text { Jurusan Komunikasi } \\
\text { Penyiaran Islam (KPI) }\end{array}$ \\
\hline
\end{tabular}

Sumber: Data penelitian

\section{Pelaksanaan kegiatan}

Pelaksanaan kegiatan laboratorium sosial dimulai dengan penyusunan buku panduan kegiatan keagamaan yang oleh mahasiswa Jurusan PMI dibantu mahasiswa Jurusan Ilmu Alquran dan Tafsir serta dibimbing dosen pendamping. Buku panduan kegiatan keagamaan ini berisi pendalaman Islam dari segi akidah, ibadah, syariah, dan muamalah. Buku tersebut disusun secara praktis agar mudah dipahami dan diimplementasikan oleh masyarakat. Penyusunan buku panduan ini dibiayai oleh Pemerintah Nagari Parambahan. 


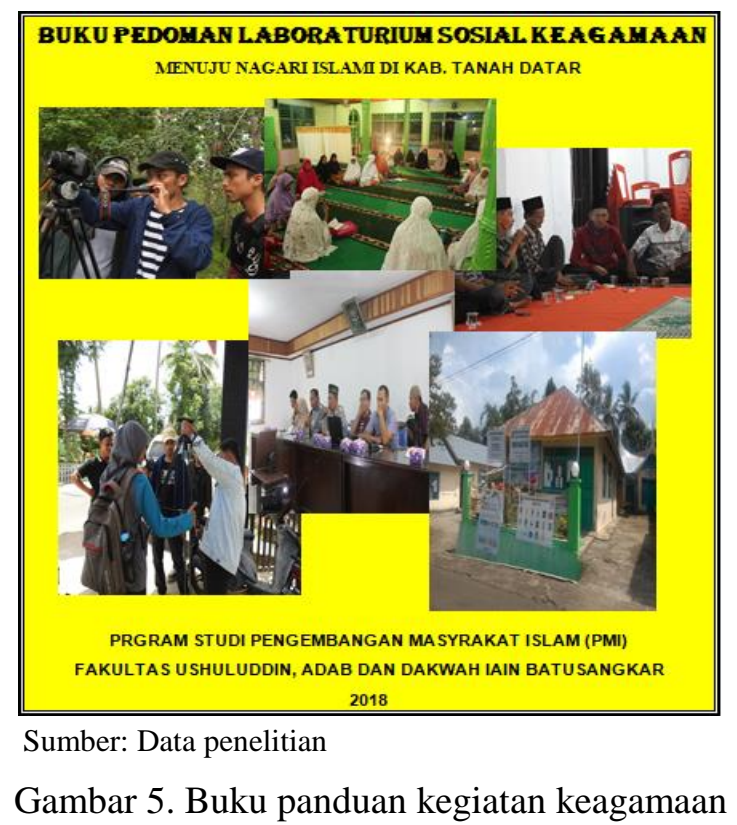

Selanjutnya, tim laboratorium sosial melakukan restrukturisasi perpustakaan dalam bentuk pembenahan sarana dan prasarana perpustakaan, dibantu mahasiswa Jurusan Ilmu Perpustakaan dan Informasi Islam berserta dosen pembimbing. Restrukturisasi perpustakaan nagari ini merupakan salah satu bentuk program Pemerintah Kabupaten Tanah Datar. Program perpustakaan nagari ini dibiayai oleh Anggaran Pendapatan Belanja Nagari yang masuk dalam Pos dan Literasi Nagari. Program literasi ini dilaksanakan sejalan dengan program pembinaan remaja masjid di Nagari Parambahan.

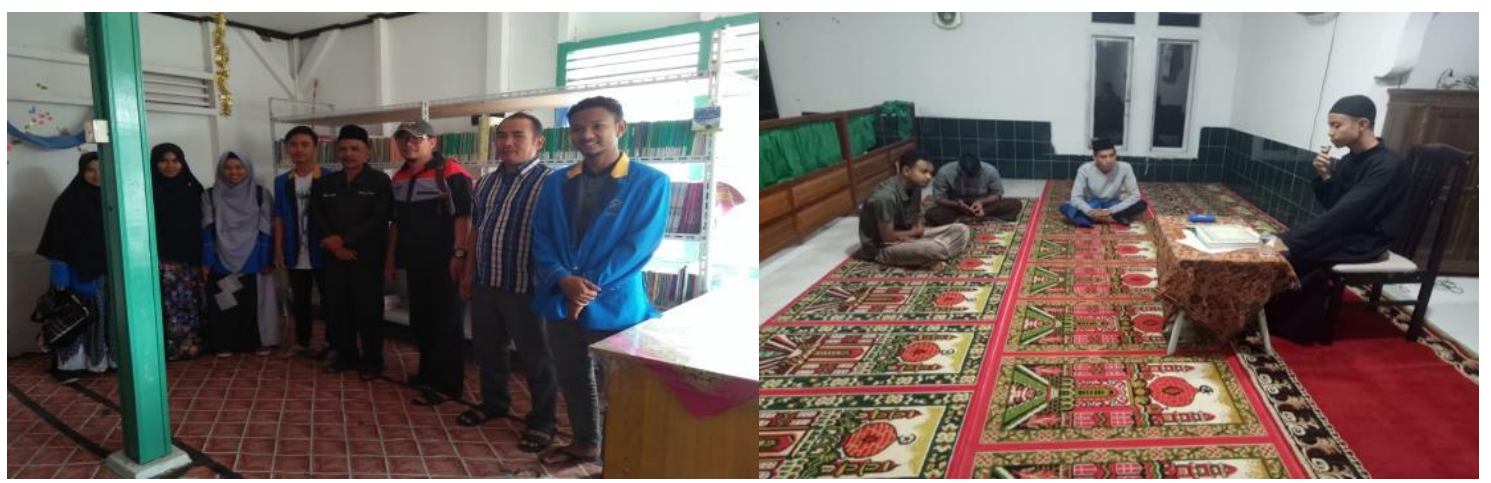

Sumber: Data penelitian

Gambar 6. Aktivitas laboratorium sosial bidang literasi dan pembinaan remaja masjid

Kepedulian terhadap permasalahan sosial diwujudkan melalui partisipasi tim laboratorium sosial dalam menyikapi fenomena penyakit masyarakat. Kegiatan yang dilakukan yaitu memberikan kontribusi dalam bentuk pandangan-pandangan umum tentang penanggulangan penyakit masyarakat. Teknis pelaksanaannya disesuaikan 
dengan sistem yang sudah ada di nagari, baik berdasarkan mekanisme adat dan maupun hukum negara.

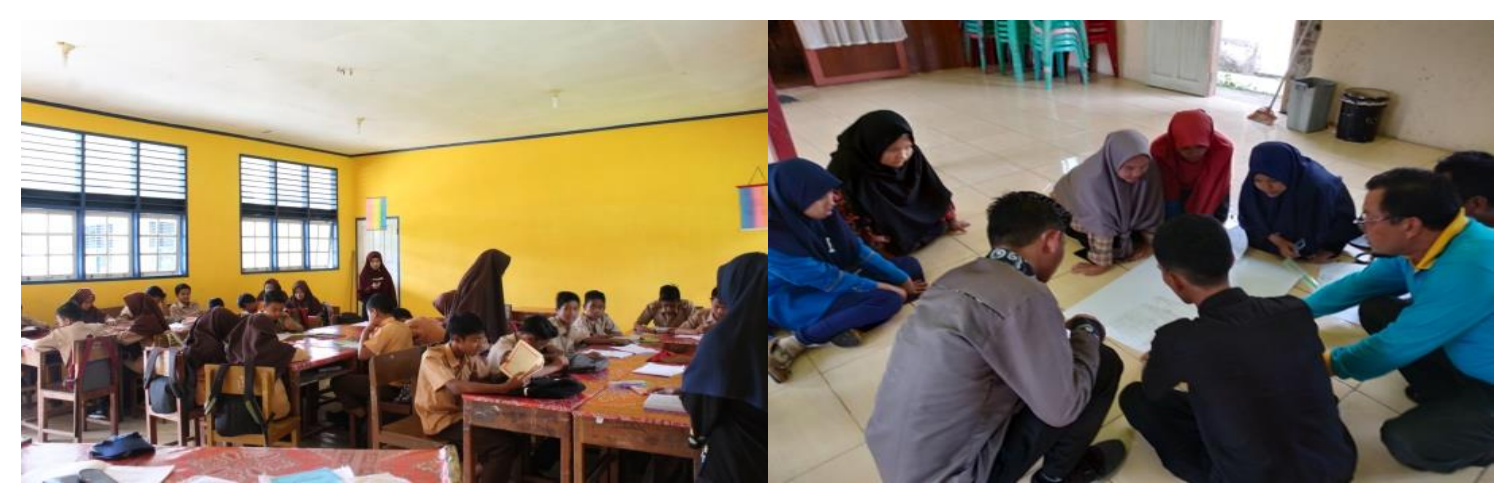

Sumber: Data penelitian

Gambar 7. Aktivitas kepedulian sosial laboratorium sosial

Penguatan lembaga keagamaan untuk merestrukturisasi lembaga-lembaga keagamaan yang ada di Nagari Parambahan dilakukan dengan mendorong pembentukan kepengurusan yang baru, serta mendorong lembaga tersebut untuk memahami peran serta fungsi lembaga. Salah satu bentuk kontribusi yang dilakukan tim laboratorium sosial adalah meninjau kembali anggaran dasar dan anggaran rumah tangga masingmasing lembaga keagamaan.

Untuk mengoptimalkan peran mahasiswa dalam laboratorium sosial, dibentuk beberapa lembaga kegiatan keagamaan baru seperti pendirian rumah tahfiz. Pendiriannya ada yang difasilitasi oleh nagari dan ada yang difasilitasi oleh warga nagari individu yang berada di perantauan, yang mempunyai kepedulian terhadap kegiatan keagamaan di kampungnya. Seluruh hasil kegiatan laboratorium sosial yang difasilitasi nagari dan ICD, seluruhnya didokumentasikan mahasiswa PMI dibantu mahasiswa KPI.

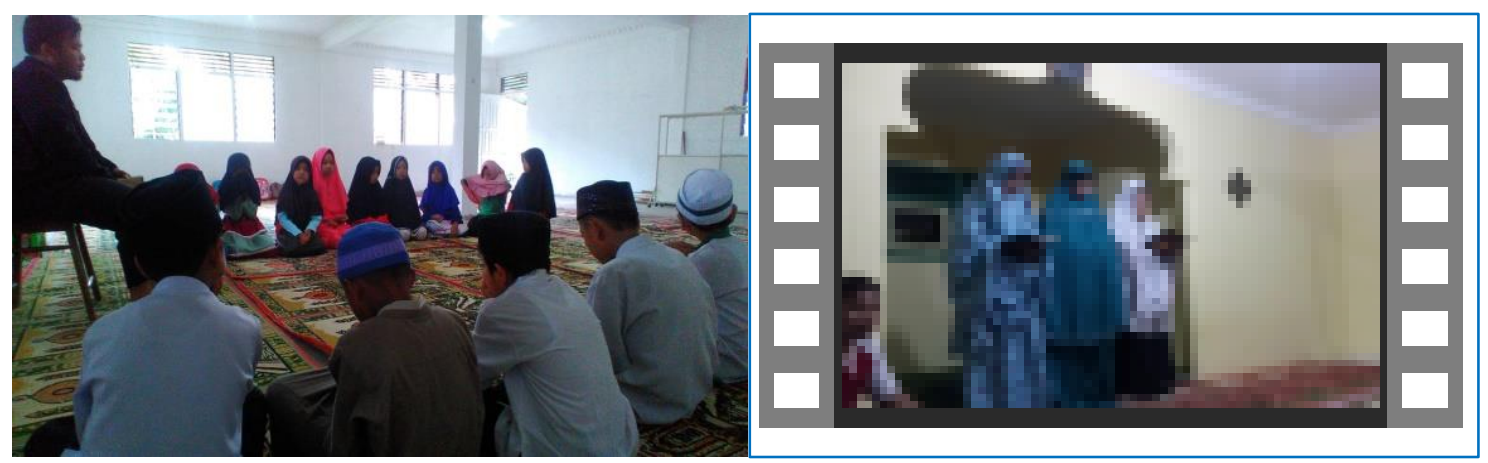

Sumber: Data penelitian

Gambar 8. Aktivitas aboratorium sosial bidang tahfiz dan video didikan subuh 


\section{Monitoring dan evaluasi}

Proses monitoring dan evaluasi merupakan salah satu tugas penting yang harus dilakukan dalam memanajemen suatu proyek. Semua anggota tim yang menjalankan proyek harus mengetahui setiap pencapaian yang secara tepat waktu dan akurat. Setiap pencapaian yang terjadi nantinya akan dibandingkan dengan rencana awal yang telah dibuat sebelumnya. Tujuannya agar proyek yang dijalankan dapat semirip mungkin bahkan sesuai dengan rencana awal yang ditetapkan (Wijaya, 2018). Pelaksananaan kegiatan monitoring tersebut bertujuan untuk mengawasi kegiatan baik secara langsung maupun tidak langsung terhadap program kerja yang telah dilaksanakan.

Pelaksanaan monitoring laboratorium sosial keagamaan dilaksanakan oleh pihak kampus dan pihak nagari. Tujuan pelaksanaan kegiatan monitoring menurut Tantan \& Muhatadi (2013) untuk mengetahui kecocokan dan ketepatan kegiatan yang dilaksanakan dengan rencana yang telah disusun. Monitoring digunakan pula untuk memperbaiki kegiatan yang menyimpang dari rencana, mengoreksi penyalahgunaan aturan dan sumber-sumber, serta untuk mengupayakan agar tujuan dicapai seefektif dan seefisien mungkin.

Evaluasi kegiatan bertujuan untuk menilai tingkat keberhasilan laboratorium sosial di Nagari Parambahan. Evaluasi program merupakan proses untuk mengetahui apakah tujuan telah terealisasi dan sebagai upaya menyediakan informasi untuk disampaikan kepada pengambil keputusan (Muhatadi, 2013). Evaluasi dilakukan melihat seluruh kegiatan yang telah dilaksanakan, baik yang melibatkan tim, program kerja tim, sarana dan prasarana, serta peran serta masyarakat dalam kegiatan laboratorium sosial.

\section{Simpulan}

Kehadiran laboratorium sosial di Nagari Parambahan, Tanah Datar memberi manfaat bagi masyarakat nagari. Laboratorium sosial merupakan kolaborasi mahasiswa, pembimbing, dan unsur-unsur nagari meliputi wali nagari, kerapatan adat nagari, kaum cerdik pandai, alim ulama, pemuda dan bundo kanduang. Kegiatan dimulai dengan persiapan, penyusunan program, pelaksanaan kegiatan, dan evaluasi. Kegiatan laboratorium meliputi literasi sosial keagamaan, aktivitas sosial keagamaan, dan dokumentasi sosial keagamaan. Untuk mengoptimalkan peran mahasiswa dalam laboratorium sosial, dibentuk beberapa lembaga kegiatan keagamaan baru. Penelitian ini memiliki keterbatasan belum menjelaskan respons dan keterlibatan masyarakat dalam aktivitas laboratorium sosial. Gap riset ini diharapkan memberikan gagasan riset selanjutnya terkait kegiatan laboratorium sosial di Tanah Datar.

\section{Referensi}

Abdullah,N.A., \& Nasionalita, K. (2018). Pengaruh Sosialisasi terhadap Pengetahuan Pelajar Mengenai Hoax (Studi pada Program Diseminasi Informasi Melalui Media Jukrak di SMKN 1 Pangandaran). CHANNEL: Jurnal Komunikasi, 6 (1), 120-130. 
AS, J.L., Khoerrudin, M. W., \& Fitriani, W. A. (2019). Pembelajaran Pendidikan Agama Islam di Luar Jam Pelajaran sebagai Laboratorium Sosial Pendidikan Agama Islam. Al-Mujaddid: Jurnal Ilmu-ilmu Agama, 1(2), 117-129.

Bachroni, M. (2015). Pelatihan pembentukan tim untuk meningkatkan kohesivitas tim pada Kopertis V Yogyakarta. Jurnal Psikologi, 38(1), 40-51.

Chambers, R. (1994). Participatory rural appraisal (PRA): Challenges, potentials and paradigm. World development, 22(10), 1437-1454.

DKP. Kelautan, D. Perikanan, 2006. Panduan Pengambilan Data Dengan Metode Rapid Rural Appraisal (RRA) dan Participatory Rural Appraisal (PRA). Program Rehabilitasi dan Pemulihan Cadangan Sumberdaya Alam. Satker Rehabilitasi dan Pengelolaan Terumbu Karang (COREMAP II) Tahun 2006. Dirjen KP3K. DKP. Jakarta.

Emda, A. (2017). Laboratorium sebagai sarana pembelajaran kimia dalam meningkatkan pengetahuan dan ketrampilan kerja ilmiah. Lantanida journal, 5(1), 83-92.

Hendriansyah, H. (2010). Metode Penelitian Kualitatif Untuk Ilmu-ilmu Sosial. Jakarta: Salemba Humanika.

Juliawati, N. (2012). Koordinasi dan Usaha Koordinasi dalam Organisasi: Sebuah Kerangka Studi. Jurnal Administrasi Bisnis, 8(2).

Lawasi, E. S., \& Triatmanto, B. (2017). Pengaruh Komunikasi, Motivasi Dan Kerjasama Tim Terhadap Peningkatan Kinerja Karyawan. Jurnal Manajemen dan Kewirausahaan, 5(1), 47-57.

Muhatadi, T.H. (2013). Manajemen Pengembangan Masyarakat Islam (PMI). Jakarta: Press UIN Syarif Hidayatullah.

Muhyiddin, A.S. (2019). Dakwah Transformatif Kiai (Studi terhadap Gerakan Transformasi Sosial KH. Abdurrahman Wahid). Jurnal Ilmu Dakwah, 39(1), 1-14.

Mustofa, I. (2019). Praktik Service Learning Manajemen Madrasah Diniah Sebagai Laboratorium Sosial Prodi Manajemen Pendidikan Islam STAI Darussalam Nganjuk. Intizam, Jurnal Manajemen Pendidikan Islam, 3(1), 14-32.

Nasril, N. (2015). Konsep Dakwah dalam Pengembangan Masyarakat Islam. Tathwir: Jurnal Pengembangan Masyarakat Islam, 53-66.

Rinaldy, R., Nulhaqim, S. A., \& Gutama, A. S. (2017). Proses Community Development pada Program Kampung Iklim di Desa Cupang Kecamatan Gempol Kabupaten Cirebon (Studi Kasus Program Bank Sampah Dalam Program Kampung Iklim). Prosiding Penelitian dan Pengabdian kepada Masyarakat, 4(2).

Riyadi, A. (2019). Desain Pengembangan Laboratorium Dakwah: Studi Kasus UIN Walisongo Semarang. Jurnal Komunikasi Islam, 9(1), 128-153.

Sofah, R., \& Sucipto, S. D. (2017, August). Optimalisasi Pemanfaatan Laboratorium dalam Implementasi Kurikulum Bimbingan dan Konseling Berbasis KKNI Prodi BK FKIP Universitas Sriwijaya. In Proceeding Seminar dan Lokakarya Nasional Bimbingan dan Konseling 2017 (Vol. 1, pp. 239-247). 
Soleh, C. (2014). Dialektika pembangunan dengan pemberdayaan. Fokusmedia.

Utari, R. (2017). Penguatan dan Perluasan Fungsi Laboratorium pada Rumpun Ilmu Sosial di Perguruan Tinggi. Dinamika Pendidikan, 22(1), 16-26.

Wijaya, C.A. (2018). Sistem Monitoring dan Evaluasi Pengelolaan Program Studi di Institusi Pendidikan Tinggi. Indonesian Journal of Information Systems, 1(1), 13 24.

Zakaria, Z. (2018). Modifikasi Konsep Participatory Rural Apraisal untuk Pembekalan Kuliah Kerja Nyata Mahasiswa di Jawa Barat, Indonesia. Dharmakarya, 7(1), 3845 . 